\title{
Politisasi Perekrutan Anggota Badan Penyelenggara Pemilu Ad Hoc: Studi Kasus di Kabupaten Tanjung Jabung Timur, Jambi
}

\section{Mardiana}

Pascasarjana Politik dan Pemerintahan, Universitas Gadjah Mada

\begin{abstract}
Abstrak:
Kehadiran badan penyelenggara Pemilu Ad Hoc di baik tingkat kecamatan, kelurahan, dan Tempat Pemungutan Suara (TPS) secara regulasi hadir untuk mendukung penyelenggaraan pemilu secara teknis di lapangan. Praktiknya, perekrutan anggota badan penyelenggara pemilu ad hoc juga bisa jadi sangat politis. Penelitian ini didasarkan pada studi kasus di Kabupaten Tanjung Jabung Timur Provinsi Jambi dalam konteks pilkada 2015. Politisasi iini melibatkan birokrasi dan partai politik secara simultan. Politisasi di level birokrasi berlangsung melalui jalur PNS (Pegawai Negeri Sipil) dan jalur pilkades. Politisi ini terjadi melalui kanal-kanal seperti lewat jalur camat, kades/lurah, kadus, ketua RW, ketua RT, tokoh masyarakat, tokoh pemuda, dan PPS hasil politisasi kades/lurah. Politisi perekrutan anggota badan penyelenggara pemilu ad hoc semakin kuat ketika sampai di level birokrasi di hirarkhi bawah dikarenakan aturan rekrutmen yang longgar, tidak spesifik, dan kurangnya campur tangan KPU kabupaten/kota di hierarki tingkatan bawah tersebut.
\end{abstract}

\section{Kata Kunci:}

rekrutmen; politisasi rekrutmen; penyelenggara pemilu Ad Hoc; pemilu

\section{Pendahuluan}

PPK (Panitia Pemilu Kecamatan), PPS (Panitia Pemilu Sementara), dan KPPS

(Ketua Penyelenggara Pemilu Sementara) merupakan petugas ad hoc yang dibentuk menjelang Pemilu dan dibubarkan setelah Pemilu berlangsung. Mempunyai tugas 'ujung tombak' dari proses pemilu karena berkaitan langsung dengan proses penetapn DPT (Daftar Pemilih Tetap), proses pemungutan, dan penghitungan suara. Namun demikian, badan penyeenggara pemilu ad hoc ini bukan sekedar badan yang berfungsi teknis. Secara politis, karena mempunyai nilai strategis, peluang politisasi dalam proses rekrutmennya sangat mungkin terjadi.

\section{Korespodensi:}

Departemen Politik dan Pemerintahan, Fakultas IImu Sosial dan IImu Politik, Universitas Gadjah Mada, Jl. Sosio Yustisia No.1, Karang Malang, Caturtunggal, Kec. Depok, Kabupaten Sleman, Daerah Istimewa Yogyakarta 55281

Email: kapparamardiana@gmail.com. 
Proses rekrutmen PPK, PPS, dan KPPS di Kabupaten Tanjung Jabung Timur menarik ditelusuri untuk memahami cara kerja politisasi dalam proses rekrutmen badan penyelenggara pemilu ad hoc, mengingat kabupaten yang baru lahir dari pemekaran Kabupaten Tanjung Jabung di Provinsi Jambi (UU RI Nomor 54 Tahun 1999) itu baru tiga kali mengalami periode Pemilu semenjak pemekarannya. Kabupaten ini menjadi lumbung suara Partai Amanat Nasional (PAN) yang selalu keluar sebagai pemenang selama tiga periode Pemilu legislatif (2004-2009, 2009-2014, 2014-2019) dan tiga periode Pilkada (2006-2011, 2011-2015, 2015-2020). Meski merupakan kabupaten baru, proses politik yang muncul, termasuk dalam perekrutan badan penyelenggara pemilu ad hoc sudah sangat kuat.

Artikel ini bermaksud mendiskusikan politisasi perekrutan anggota badan penyeenggara pemilu ad hoc (PPK, PPS dan KPPS) degan mencakup 2 isu penting. Pertama, cara kerja politisasi dalam proses rekrutmen PPK, PPS, dan KPPS di Tanjung Jabung Timur. Kedua, dampak politisasi badan penyelenggara pemilu terhadap profesionalitas PPK, PPS, dan KPPS terpilih?

Dalam menjelaskan politisasi, penting kiranya menengok karya Deutsch (Deutsch, Merton and Coleman, 2000). Dalam Kartono (1989: 6) menjelaskan bahwa politicization is making things political. Secara umum, politisasi dimaknai sebagai proses yang membuat segala hal menjadi politik. Dalam Shaleh, 2003: 39) kemudian memjabarkan lebih mendetail definisi politisasi sebagai sebuah proses yang tidak hanya terpaku pada satu aspek saja tetapi dapat mencakup banyak aspek kehidupan yang dapat dijadikan obyek politik untuk dimanipulasi dan direkayasa sedemikian rupa demi kepentingan pelaku. Pendapat Deutsch dan Shaleh di atas dipakai sebagai rujukan untuk mengidentifikasi unsur-unsur yang dikandung dalam sebuah proses politisasi, yang menurut Bayu Aji Dewantara (2017) meliputi unsur subjek (pelaku), objek (sasaran), tujuan, dan instrumen (media).

Dalam menjelaskan politisasi perekrutan badan penyelenggara pemilu ad hoc, ada beberapa unsur yang penting didiskusikan. Pertama, pelaku politisasi dalam rekrutmen badan penyelenggara pemilu ad hoc diperkirakan berasal dari kelompok partai politik, dalam hal ini Partai Amanat Nasional (PAN). Kedua, sasaran politisasi dalam rekrutmen badan penyelenggara pemilu ad hoc adalah PPK, PPS, dan KPPS yang bertugas melaksanakan penyelenggaraan teknis pemilu di tingkat kecamatan, desa/kelurahan, dan TPS. Ketiga, tujuan pelaku yang berasal dari kelompok partai politik dalam kasus ini dapat dipahami sebagai usaha untuk mendukung kemenangan kandidatnya dalam Pemilu/Pilkada. Keempat, instrumen yang dipergunakan pelaku dalam politisasi badan penyelenggara pemilu ad hoc ini adalah birokrasi daerah.

Munculnya kasus pelanggaran Pemilu yang melibatkan PPK, PPS, dan KPPS menurut Surbakti \& Nugroho (2015: 72-73) berkaitan erat dengan temuan beberapa kelemahan persyaratan dalam proses rekrutmen panitia Pemilu. Pertama, di tingkat PPK, calon yang direkrut dari aparatur sipil birokrasi daerah masih menjadi pilihan favorit, 
diduga kuat akan rawan negosiasi kepentingan dengan partai politik penguasa. Kedua, di tingkat PPS, calon diusulkan kepala desa dan Lembaga Permusyawarahan Desa atau Lurah dan Dewan Kelurahan yang diduga belum mampu bersikap netral. Pengusul mempunyai kepentingan politik dan memanfaatkan pencalonan PPS untuk mengamankan kepentingan partai politik atau calon tertentu. Ketiga, di tingkat KPPS, kompetensi calon dinilai belum tentu netral dari kepentingan politik tertentu. Kepentingan partai politik maupun calon sangat terbuka luas memberi pengaruh pada pengambilan keputusan dan komposisi petugas KPPS dikarenakan PPS sebagai pihak yang berwenang membentuk KPPS juga dipilih melalui prosedur yang belum tentu netral.

Sementara Surbakti dan Nugroho lebih menyoroti persyaratan rekrutmen penyelenggara pemilu ad hoc yang lemah dan rawan dipengaruhi kepentingan, Ugues dalam pandangan Norris, Frank, \& Coma (2014) lebih melihat dampak politisasi terhadap kinerja badan penyelenggara Pemilu. Ugues mendasarkan kajiannya sepanjang 1980-an dan 1990-an pada rezim Pemilu di El Salvador, Guatemala, Honduras, dan Nicaragua. Menurutnya, ketika pemilu melibatkan multipartai yang relatif setara dalam hal kekuatan dan pengaruh politik tanpa satupun grup yang bersifat dominan dan memaksakan kepentingan dalam proses pembentukan badan penyelenggara pemilu, maka cenderung akan melahirkan pembentukan badan penyelenggara pemilu dengan negosiasi.

Di sisi lain, badan penyelenggara pemilu yang lahir dari satu partai dominan, koalisi, atau bahkan dari militer akan menghalangi fungsi badan penyelenggara pemilu yang otonom dan imparsial. Apabila dasar rekrutmen hanya dilandasi pengalaman, keahlian, dan pengetahuan dari calon penyelenggara, rekrutmen akan menghasilkan level politisasi rendah. Sedangkan dasar rekrutmen yang didasari hanya afiliasi partisan akan menghasilkan level politisasi tinggi. Tetapi apabila dasar rekrutmen dilandasi pengalaman, keahlian, pengetahuan sekaligus afiliasi partisan makan akan menghasilkan level politisasi yang lebih tinggi lagi.

The International IDEA (2012) memandang bahwa model ideal dari penyelenggara pemilu di negara-negara demokrasi berkembang adalah secara legal independen dari unsur pemerintahan dan ciri-ciri pengurus adalah independen secara politik yang telah terbukti secara kuat berkorelasi dengan pemilu yang bebas dan adil di Latin Amerika. Dari sini, tampak jelas posisi dan peran birokrasi sangat menentukan kualitas proses rekrutmen badan penyelenggara pemilu ad hoc. Sehingga besar dugaan apabila terdapat hubungan antara politisasi birokrasi dan politisasi badan penyelenggara pemilu dalam menimbulkan dampak politisasi terhadap kinerja badan penyelenggara pemilu.

Kekuatan dampak politisasi birokrasi ditentukan dengan menggunakan patokan Harold Crouch dalam Tjokrowinoto (2001: 113) yang meliputi tiga karateristik utama, yaitu lembaga politik yang dominan melingkupi birokrasi, tidak ada penyeimbang atau 
kekuatan dari lembaga lain yang mampu mengontrol kekuatan birokrasi, dan masyarakat secara politis dan ekonomis bersikap pasif. Semakin terpenuhinya ketiga karateristik tersebut di atas, maka dampak politisasi birokrasi akan semakin kuat kadarnya. Martini (2013) dalam Politisasi Birokrasi di Indonesia menerjemahkan kekuatan dari dampak politisasi birokrasi menjadi fenomena politisasi birokrasi. Salah satu fenomena politisasi birokrasi yang paling sering terjadi di Indonesia adalah usaha penguasa untuk memobilisasi pegawai negeri pada saat pemilu dan pilkada. Pernyataan ini sejalan dengan penemuan Ramlan Surbakti dan Kris Nugroho yang menyatakan kurangnya netralitas dalam tubuh PPK yang diisi aparatur sipil dan PPS yang diisi dari kontribusi kepala desa maupun lurah.

Politisasi badan penyelenggara pemilu tidak berlangsung secara tunggal, ada proses politisasi birokrasi yang melatarbelakangi sebelumnya. Walaupun secara tidak langsung penelitian-penelitian tersebut di atas mengisyaratkan hal tersebut tetapi tidak terdapat penjelasan tentang bagaimana cara kerja politisasi yang berlapis tersebut dalam proses rekrutmen badan penyelenggara pemilu ad hoc.

Guna memenuhi tujuan-tujuan di atas, makla artikel ini menggunakan metode deskriptif kualitatif. Lokus penelitian ini berada di Kabupaten Tanjung Jabung Timur dengan menimbang keberadaan PAN (Partai Amanat Nasional). Terdapat dua jenis data yang dipergunakan, yaitu data primer dan data sekunder. Sumber data sekunder yang dikumpulkan diantaranya: (1) Arsip KPU yang berkaitan dengan daftar nama PPK, PPS dan KPPS terpilih untuk Pilkada 2015, (2) Daftar Nama Perangkat Desa Periode 20132019, (3) Daftar Nama Pengurus PAN di lingkungan Tanjung Jabung Timur Periode 2010-2015, (4) Pemberitaan media berkaitan dengan Pilkada 2015 (5) Kajian Banwaslu RI berkiatan hasil pengawasan Pilkada 2015 (6) Laporan pengawasan Panwaslu Tanjung Jabung Timur berkaitan dengan Pilkada 2015. Daftar nama di atas digunakan sebagai dasar pemilihan narasumber yang akan diwawancarai. Sementara pemberitaan media dan laporan pengawasan dari Banwaslu-Panwaslu akan menjadi data pendukung argumen atas hasil penelitian. Selanjutnya, data primer diperoleh dari wawancara dengan KPU, PAN, birokrasi daerah (kades dan aparatur PNS kecamatan/kelurahan), dan panitia pemilu (PPK, PPS, dan KPPS).

\section{Pencalonan Perempuan sebagai Anggota Legislatif}

Menjawab pertanyaan penelitian, secara sederhana berikut gambaran cara kerja politisasi dalam proses rekrutmen badan penyelenggara Pemilu ad hoc di Kabupaten Tanjung Jabung Timur. 
Tabel 1. Skema Politisasi Proses Rekrutmen Badan Penyelenggara Pemilu Ad Hoc

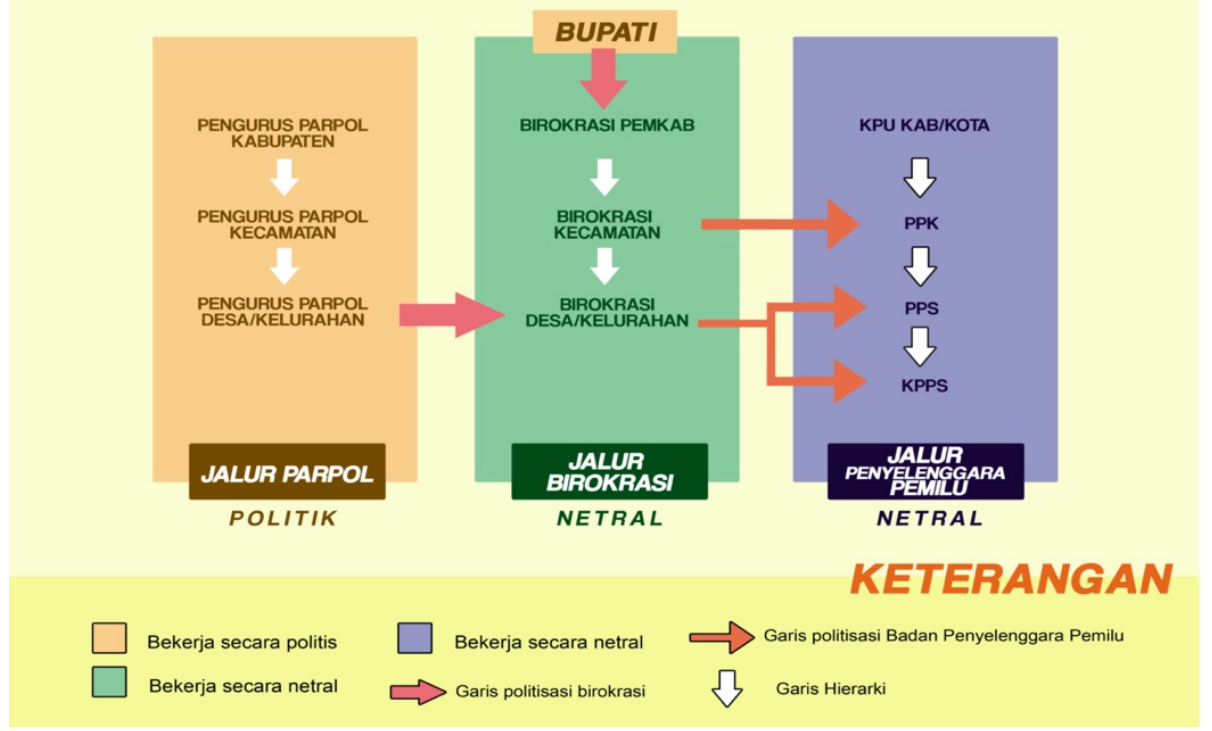

Sebagaimana dalam tabel, politisasi tahap pertama terjadi di level birokrasi. Dari 73 desa diduga kuat terdapat 28 pengurus PAN yang menjabat kepala desa, maka 38,35\% kader PAN telah menguasai jabatan strategis di tingkat desa. Sementara 20 kelurahan yang dijabat lurah sebagai jabatan PNS karier telah dipastikan akan diduduki 'orangorang PAN' atas dasar penunjukan bupati yang notabene adalah kader PAN. Sehingga 48 orang PAN yang menduduki jabatan kades/lurah dari 93 desa/kelurahan yang ada maka tercatat 51,61\% penguasaan PAN di Tanjung Jabung Timur untuk tingkat desa/kelurahan. Angka tersebut di luar simpatisan PAN yang mencalonkan diri menjadi kades dalam Pilkades. Sehingga sangat mungkin angka persentase penguasaan PAN di tingkat desa/kelurahan jauh melampaui persentase 51,61\% di Kabupaten Tanjung Jabung Timur.

Salah seorang informan menjelaskan, "Kades Tanjabtim sebagian besar berasal dari unsur PAN." (wawancara M, Ketua Ranting PAN Desa Kota Harapan, 18 November 2017). Penjelasan ini diperkuat oleh informan lain, "Kepala desa bukan 90\% tetapi 100 \% orang PAN di Tanjabtim. Tidak akan kemana-mana. Namanya politik dinasti." (wawancara R, Ketua KPPS Kota Harapan, 24 Oktober 2017). Orang-orang PAN memiliki peran sosial yang berfungsi dengan baik tidak hanya melalui jalur partai tetapi juga dengan memanfaatkan jalur birokrasi, salah satunya mampu merangkul tokoh-tokoh masyarakat setempat untuk dijadikan kader, pengurus, atau simpatisan. Informan menjelaskan: 
"Tokoh masyarakat yang berpengaruh di setiap daerah direkrut menjadi bagian dari PAN... Tugas kades adalah mengendalikan dan mengarahkan tokoh masyarakat agar pro dengan PAN. Cukup banyak tokoh masyarakat yang harus saya kendalikan di Desa Sungai Toman, berbeda dengan Kades Sinar Wajo (Ratnawati-pengurus PAN) yang memiliki tugas mengendalikan hanya 3 (tiga) tokoh masyarakat." (wawancara SA, Kades (Pjs) Sungai Toman, PNS Pemda Tanjung Jabung Timur, 18 Juli 2017).

Loyalitas simpatisan PAN sangat terasa, tidak saja pada masyarakat umum, tetapi juga pada aparatur birokrasi yang tunduk pada penguasa.

“...Waktu Pilkada, Bupati menginstruksikan kepada kepala dinas selanjutnya kepala dinas menginstruksikan ke tingkat bawahnya. Camat, lurah, dan kepala desa dikumpulkan untuk 'bergerak', saya ketika menjadi camat ketika disuruh bergerak oleh bupati ya saya bergerak..." (wawancara S, Sekretaris KPU Tanjung Jabung Timur, mantan Camat Dendang, dan mantan Kabag Umum Kantor Bupati Tanjung Jabung Timur, 30 Oktober 2017).

Intruksi itu sifatnya berjenjang. Penguasa akan memberi instruksi pada pejabat birokrasi. Pejabat akan menginstruksikan bawahannya untuk melanjutkan instruksi tersebut hingga ke staf pelaksana di level paling rendah. Selanjutnya, di tingkat kecamatan, desa dan kelurahan, bupati akan mengumpulkan camat, lurah, maupun kades untuk ikut serta dalam menyukseskan kandidat bupati PAN memenangkan kontestasi Pilkada. Kasus sengketa pilkada 2011 berhasil menguak fakta tersebut. ${ }^{1}$

Sementara pada Pilkada 2015 dalam Bawaslu RI (2016), temuan Banwaslu dengan Nomor Laporan: 07/LP/PILBUP/XII/2015 menyebutkan adanya dugaan keterlibatan Pejabat PNS dalam politik praktis dengan pertemuan, ajakan, himbauan, seruan kepada tenaga honorer untuk mendukung salah satu pasangan calon bupati dan wakil bupati Kabupaten Tanjung Jabung TImur (Romi Hariyanto, SE sebagai calon Bupati dan Zumi Zola Zulkifli, STP, MA sebagai calon gubernur dari PAN) dalam bentuk rekaman video.

Cara kerja politisasi yang kedua terjadi di Badan Penyelenggara Pemilu Ad Hoc sendiri. Keinginan memenangkan kontestasi pilkada merupakan kewajaran dari seorang penguasa selaku aktor politik. Tetapi ketika penguasa cenderung melakukan politisasi birokrasi untuk kepentingan kontestasi politiknya, hal tersebut menjadi tindakan yang melanggar azas pemilu yang adil. Sayangnya, kondisi itu sulit dihindari, kepentingan kades dan lurah menunjukkan loyalitas sebagai bawahan penguasa terkadang cenderung mencampuradukkan urusan publik dengan politik. Sehingga usaha menyukseskan kemenangan penguasa dalam pilkada pun ditindaklanjuti sebagai wujud dedikasi kerja.

Sebagaimana penjelasan informan, "Pada Pilkada 2015 persentase pemenangan Romi-Robby (PAN) mencapai 60\% lebih meningkat dibandingkan Pilkada sebelumnya yang hanya mencapai 50\%" (wawancara SA, 2017). Penjelasan ini diperkuat informan lain yang menyatakan, "Iya, ada target yang diutarakan oleh kades. Waktu itu kades 
menginginkan kami mencapai angka $70 \%$ atau 80\%. Katanya, biar jadi anak kesayangan, sehingga kalau ada permintaan desa, yang atas gampang mengabulkan. Tetapi, kami sudah merasa kemenangan 60\% lebih di TPS udah cukup" (wawancara R, 2017). Menguatkan hal ini, informan berikutnya menjelaskan,“...Camat, lurah, dan kepala dinas yang dianggap berjasa dalam pemenangan penguasa akan naik jabatan” (wawancara S, 2017).

Untuk mewujudkan kemenangan penguasa dalam pemilihan, perangkat desa/kelurahan yang lahir dari proses politisasi birokrasi itu kemudian melakukan politisasi pada badan penyelenggara pemilu ad hoc. Sebagaimana informan, "Kades memilih orang-orang muda untuk menduduki jabatan PPS maupun KPPS, agar mudah diintervensi. Bukan dari tokoh masyarakat, tokoh masyarakat adalah penggerak suara yang punya peran lain" (wawancara SA, 2017).

Seperti yang diutarakan oleh Surbakti \& Nugroho (2015: 73), kepala desa menunjuk orang-orang pilihan berdasarkan masukan dari pihak berkepentingan. Dalam kasus TanjungJabung Timur, kades memasukan orang-orang dari unsur PAN atau unsur keluarga dan kerabat dalam jabatan penyelenggara teknis pemilu. "PPS direkrut berdasarkan kedekatan dengan kades, seperti keluarga kades, keluarga sekdes", demikian Mustaqim, Ketua KPU Tanjung Jabung Timur menjelaskan (wawancara 19 juli 2017). Hal ini senada dengan pernyataan informan, "Saya langsung ditunjuk Sekdes (untuk menjadi ketua PPS). Kebetulan Sekdes adalah teman" (wawancara P, 20 November 2017).

Hal ini dikuatkan dengan penjelasan informan lain, dimana, “... ada sebagian atas dasar unsur kedekatan atau keluarga" (wawancara K, Ketua PPK Nipah Panjang, 20 November 2017). Informan lain menyebutkan, "Saya menjadi ketua KPPS ditunjuk langsung oleh kepala desa...PPS juga ditunjuk langsung dari Pak kades... Awalnya, saya mengajukan keberatan kepada kades, tetapi menurut kades tidak ada lagi orang makanya saya ditunjuk sebagai ketua KPPS. Pernah ada pihak tim lawan yang mengetahui dan mengancam akan mengadukan saya apabila saya masih tetap menjadi ketua KPPS, segera saya sampaikan kepada kades, dan beliau meyakinkan saya. Dan memang tidak terjadi apa-apa.” (wawancara Rahmansyah, 2017).

Kades Kota Harapan yang merupakan unsur PAN memanfaatkan kekuasaannya untuk mendudukkan salah satu pengurus ranting PAN yang masih aktif di jajaran KPPS sebagai ketua. Salah satu fakta yang menunjukkan keterkaitan erat antara politisasi birokrasi dan politisasi badan penyelenggara pemilu ad hoc.

\section{Model Praktik Politisasi Birokrasi}

Berdasarkan temuan penelitian, praktik politisasi birokrasi dalam kaitannya dengan dapat dibedakan kedalam 2 model. Pertama, politisasi birokrasi melalui jalur PNS. Terkait ini, yang dilakukan adalah dengan menempatkan PNS pada jabatan karier di Tingkat Kecamatan dan Desa/Kelurahan Berdasarkan Afiliasi Politik. Kasus Pilkada 
Bupati Tanjung Jabung Timur tahun 2011 terkuak fakta mengenai hubungan afiliasi politik PNS dengan jabatan kariernya.2 “... Camat, lurah, dan kepala dinas yang dianggap berjasa dalam pemenangan penguasa akan naik jabatan", ujar informan (wawancara S, 2017). Bupati disebut akan memata-matai aparatur birokrasi melalui orangorang kepercayaannya untuk mengetahui afiliasi politik bawahannya. Bagi bupati, sangat berbahaya untuk mendudukkan orang-orang berafiliasi politik bertentangan dengannya di jabatan camat, lurah, sekcam, seklur, dan sekdes pada masa pemilu dan pilkada. Cara yang kedua dengan memobilisasi PNS Melalui Jabatan Karier di Tingkat Kecamatan dan Desa/Kelurahan. Selaku PNS yang pernah menjabat camat dan kabid di Pemda sebelum menjadi Sekretaris KPU Kabupaten Tanjung Jabung Timur, informan membagi pengalamannya melalui wawancara sebagai berikut:

\begin{abstract}
"...Politisasi lebih mungkin berdampak di pemda pada PNS, bupati menginstruksikan kepada kepala dinas selanjutnya kepala dinas menginstruksikan ke tingkat bawahnya. Camat, lurah, dan kepala desa dikumpulkan untuk 'bergerak', saya ketika menjadi camat ketika disuruh bergerak oleh bupati ya saya bergerak. Tetapi ketika menjadi sekretaris KPU, saya memberikan pengertian pada bupati dan bupati memaklumi itu. Pada birokrasi daerah, politisasi memberikan efek yang kuat, karena di sana ada kompensasi yang berimplikasi pada karier. Dan bisa jadi sulit dibuktikan..." (wawancara S, 2017).
\end{abstract}

Pernyataan narasumber di atas didukung dengan temuan Panwaslu Tanjung Jabung Timur Atas Pelanggaran Pilkada 2015 Nomor Laporan: 07/LP/PILBUP/XII/2015 berupa rekaman video yang menyebutkan adanya dugaan keterlibatan PNS dalam Pilkada, dalam kasus ini pejabat PNS yang dilaporkan tersebut membuat pertemuan dengan memberikan ajakan, himbauan, dan seruan kepada tenaga honorer untuk mendukung calon bupati dan calon gubernur yang diusung PAN. Walaupun kasus ini tidak dapat ditindaklanjuti dikarenakan usaha tersebut dilakukan sebelum tahapan penetapan kandidat Pilkada. Tetapi, nama calon bupati dan calon gubernur tersebut secara resmi telah didukung partai.

Penguasa menggunakan jabatan dalam tubuh birokrasi kecamatan dan desa/kelurahan untuk memobilisasi PNS demi mendukung kepentingan politiknya. Jabatan camat, lurah, sekcam, seklur, dan sekdes sering mengalami perombakan ketika masa menjelang pemilu ataupun pilkada. Informan menjelaskan, "Saya diangkat menjadi pjs kades bulan April 2015. Ada 43 Pjs Kades yang diangkat bulan April tersebut" (wawancara SA, 2017).

Model politisasi birokrasi yang kedua adalah melalui jalur Pilkades. Cara pertama yang digunakan dengan Memanfaatkan Peran Birokrasi Kabupaten Dalam Urusan Administrasi Calon Kades.

"Semua kepala desa terpilih di Tanjabtim dimenangkan oleh PAN... Karena biasanya ditanyakan dulu dengan kepala ranting mengenai calon kades pro ke PAN 
atau tidak. Kalau dak pro, biasanya dak diluluskan pas di atas bahannya. Pemilihan tetap langsung oleh rakyat, tetapi sebelum berkas naik diselidiki dulu, nah misal sudah jelas orang pro ke PAN diluluskan berkas pendaftarannya, jadi walaupun siapa yang menang dalam pemilihan tetap orang PAN. Pendaftarannya dulu, berkas pendaftaran maksudnya. Kan kita ranting PAN, nanti survey di desa" (wawancara R, 2017).

Menurut narasumber, PAN memanfaatkan peran birokrasi daerah yaitu Bidang Pemerintahan Desa BPMPDK (Badan pemberdayaan Masyarakat Pemerintahan Desa Kelurahan) dalam melakukan seleksi administrasi calon kades, birokrasi melakukan permainan pada tahapan pendaftaran kades, ketika berkas calon kades dikumpulkan maka pengurus ranting PAN akan diberitahukan berkaitan dengan nama-nama calon kades yang mendaftar, selanjutnya pengurus ranting PAN akan bertugas melakukan peninjauan di lapangan untuk mencari informasi berkaitan dengan calon-calon kades tersebut. Calon kades yang diindikasikan kontra PAN akan dieliminasi dari daftar calon kades, sementara calon kades yang diindikasikan pro PAN akan mendapatkan 'kartu start' untuk dapat mengikuti pemilihan kepala desa, sehingga seluruh calon kades dijamin pengurus ranting PAN memiliki afiliasi politik dengan PAN. Selanjutnya, PAN menyerahkan sepenuhnya pada masyarakat desa untuk menentukan pemenang kades yang mereka inginkan.

Cara yang kedua adalah dengan memberikan dukungan pada salah satu calon di Pilkades. Pilkades diwarnai peran besar PAN untuk memenangkan kandidatnya. Berdasarkan pengakuan salah satu pengurus penting PAN, ketika PAN berbicara mengenai Pilkades, maka PAN dapat dibilang terlibat secara tidak langsung dan tidak terang-terangan. Pemberian dukungan pada salah satu calon dilakukan namun cara kerjanya lebih tertutup dari pada yang dilakukan di Pilkada. Karena menurutnya, keterlibatan PAN yang terang-terangan cenderung akan memberikan tekanan. Informan menjelaskan, "Kalau di Pilkades, PAN dibilang terlibat, bisa, tapi tidak kelihatan. Istilahnya, ada dukungan pada salah satu calon tapi tidak kelihatan. Ada "bisik-bisik" yang dilakukan PAN. Tidak kelihatan kerjanya, karena kalau kelihatan nanti akan ada tekanan” (wawancara M, 2017). Maksud dari 'tekanan' di sini, diperkirakan Penulis adalah adanya keterlibatan birokrasi seperti yang disebutkan pada poin pertama di atas.

Kemudian, cara selanjutnya adalah dengan pendekatan PAN pada calon kades terpilih. Menurut pendapat narasumber, bisa jadi pada awalnya kades terpilih bukan dari unsur PAN. Tetapi selanjutnya PAN melakukan pendekatan pada pejabat desa tersebut. "Sebenarnya dari awalnya mungkin bukan dari unsur PAN, tetapi setelah menjadi pejabat kades kemudian didekati oleh PAN", kata informan (wawancara K, 2017). Apalagi PAN, merupakan partai politik yang memiliki 'daya pikat', kader mereka paham betul 
dengan keinginan masyarakat dan mereka selalu berusaha cepat tanggap memberikan bantuan yang dibutuhkan yang biasanya berupa pembangunan fisik. Seorang informan menjelaskan,

“...Saya pribadi, saya merasa cocok dengan PAN, soalnya perhatian, pembangunan PAN ada sampai ke desa, ada perhatian. Walaupun pada saat itu kami meminta hanya melalui anggota dewan, seperti bangun musola, langgar, kita minta tolong ke pengurus, dan dibantu. Karena itu, kito ikut mereka. Pernah juga diajak masuk ke PDI-P ada juga ke Golkar, tetapi lebih memilih ke PAN, karena PAN lebih besar pengaruhnya dan perhatiannya" (wawancara M, 2017).

Dengan demikian, tidak bisa dipungkiri bahwa perangkat kecamatan, kelurahan, dan desa yang dipilih melalui pemilihan ataupun jenjang karier tidak terlepas dari dominasi PAN. PAN terus-menerus melakukan pendekatan politik secara intensif. "Ratarata Kepala Desa di Tanjabtim berasal dari unsur PAN, baik mantan pengurus ataupun simpatisan. Tokoh masyarakat yang berpengaruh di setiap daerah direkrut menjadi bagian dari PAN" (wawancara SA, 2017).

\section{Model Praktik Politisasi Badan Penyelenggara Pemilu Ad Hoc}

Adapun praktik politisasi badan penyelenggara pemilu ad hoc dilakukan dengan beberapa pola di antaranya, pertama, oleh camat. Politisasi dilakukan dengan pertama, menutup akses informasi Rekrutmen PPK kepada publik. Camat merupakan corong informasi di kecamatan berkaitan dengan rekrutmen PPK, tetapi camat lebih mendorong orang-orangnya mendaftar ke KPU sebelum menyasar publik.

Seorang informan menjelaskan, "(Saya) mendaftar sendiri ke KPU, disuruh camat, menggantikan anggota lama" (wawancara IH, Anggota PPK Berbak, 20 November 2017). Sedangkan informan lain menjelaskan soal keterbukaan informasi, "Relatif. Di beberapa tempat, ada yang sudah banyak ada yang belum terkumpul. Tidak sama masalah di tiap tempat, mungkin kurang komunikasi, tapi kalau komunikasi bagus banyak yang mau. Tergantung komunikasi ke bawah" (wawancara YA, tokoh masyarakat Nipah Panjang, 21 November 2017).

Cara kedua melalui pengisian kekosongan pendaftar PPK. Seorang informan menjelaskan, "Tidak ada rekomendasi, jadi cuma berdasarkan wawancara dan tes tertulis. Kecuali, apabila tidak ada orang yang mendaftar maka meminta bantuan camat untuk mengirimkan nama untuk mengikuti tes PPK" (wawancara M, Kasubbag Teknis dan Hupmas KPU Kabupaten Tanjung Jabung Timur, 18 November 2017).

Politisasi berikutnya oleh kades/lurah. Di tingkat desa dan kelurahan, pola cara kerja politisasi badan penyelenggara pemilu agak berbeda dengan pola di tingkat kecamatan. Pertama, Kades/Lurah Memanfaatkan Rekomendasi untuk PPS. Menurut 
regulasi, kades dan lurah memiliki otoritas untuk memberikan rekomendasi atas calon PPS yang ingin mendaftar menjadi PPS. Minimal enam nama yang harus dikirim kades/lurah kepada KPU Kabupaten untuk mengikuti seleksi PPS. Otoritas sortir yang dimiliki kades/lurah tersebut seringnya dipergunakan untuk memasukkan orang-orang mereka dalam seleksi PPS. Seorang informan menjelaskan, "Memang rekrutmen PPS dan KPPS penunjukan langsung oleh kepala desa tetapi hanya sebatas mencari orang yang dikenal dan gampang diajak kerja" (wawancara S, 2017). Sedangkan informan berikutnya menjelaskan, "Saya langsung ditunjuk Sekdes. Kebetulan Sekdes adalah teman. Kemudian ada rapat perangkat kelurahan dengan tokoh masyarakat saya ditunjuk. Apalagi saya sudah pernah menjabat sebelumnya" (wawancara P, Ketua PPS Nipah Panjang II, 20 November 2017).

Cara kedua, Kades/Lurah menunjuk langsung KPPS. Di lapangan, tidak hanya jabatan PPS yang mampu diintervensi kades/lurah, jabatan KPPS pun dapat ditentukan langsung oleh kades/lurah. Sehingga Bahasa 'orang kita' dan 'orang mereka' akan biasa didengar selama proses rekrutmen penyelenggara pemilu ad hoc berlangsung. "Pak RT. Tidak diseleksi, langsung ditunjuk. Ada pergantian ada yang sudah menjabat 2 kali tidak boleh lagi, biasanya rata-rata aparat desa yang terlibat sebagai penyelenggara, karena tidak sampai SMA tidak lagi diikutkan", seorang ketua KPPS menjelaskan (wawancara S, 21 November 2017).

Cara ketiga dengan menutup akses informasi Rekrutmen PPS dan KPPS kepada public. Seperti halnya di tingkat kecamatan, kades/lurah di tingkat desa/kelurahan juga tidak berusaha membagikan informasi mengenai pembukaan rekrutmen PPS dan KPPS kepada masyarakat di wilayahnya. Apabila dilakukan publikasi, sifatnya hanya pada kalangan terbatas. "Sekdes memberitahukan dan menawarkan "mau tidak menjadi PPS", tidak ada tes, ketika saya bersedia langsung ditulis namanya sebagai PPS. Begitu juga dengan rekan-rekan yang lain... KPPS Sama. Ditawarkan juga oleh sekde”, ujar seorang ketua KPPS (wawancara AI, Ketua PPS SimpangJelita, 19 November 2017).

Ketiga, politisasi oleh kadus, ketua RW, dan atau Ketua RT. Politisasi badan penyelenggara pemilu yang dilakukan kadus, ketua RW dan Ketua RT hanya berada pada lingkup KPPS. PPS terpilih dengan alasan keterbatasan kemampuan sering melimpahkan otoritasnya memilih KPPS kepada kadus, ketua RW, dan ketua RT. Akibatnya, kadus, ketua RW, dan Ketua RT pun memainkan perannya dalam posisi ini. Informan menjelaskan, "(Saya) Ditunjuk ada juga. Bukan ditunjuk... tapi kita minta tolong RT mengumpulkan warganya yang berminat menjadi KPPS... Kita minta tolong RT mengumpulkan warganya yang berminat menjadi KPPS. Memang murni dari RT, kami hubungi RT saja. Dasarnya kurang lebih sesuai dengan peraturan yang berlaku" (wawancara AH, Ketua PPS Nipah Panjang I, 20 November 2017). Hal ini dikuatkan 
informan lain, "(Saya ditunjuk) Pak RT. Tidak diseleksi, langsung ditunjuk" (wawancara S, 2017). Sementara itu, informan lain menjelaskan, "KPPS ditunjuk langsung oleh PPS, tetap meminta saran dari kades/lurah, ketua RT/RW, tokoh masyarakat. Karena masyakat yang mengetahui si A atau si B yang bisa" (wawancara MA, Anggota PPK Kuala Jambi, 21 November 2017).

Keempat, politisasi oleh tokoh masyarakat atau tokoh pemuda. Dalam hal ini, alasan yang sama juga terjadi dimana PPS melimpahkan hak otoritasnya memilih KPPS kepada tokoh masyarakat atau tokoh pemuda dengan alasan pihak tersebut lebih memahami kondisi nyata di lapangan, mengenal dengan baik setiap individu, dan mampu menyeleksi secara alamiah orang-orang yang pantas duduk sebagai KPPS. Ketika tokoh masyarakat atau tokoh pemuda tersebut berafiliasi pada PAN, maka politisasi badan penyelenggara pemilu pun terjadi. Dengan kondisi penyebaran kepengurusan aktif PAN di level desa/kelurahan yang sudah sangat merata, kecil kemungkinan tokoh masyarakat dan tokoh pemuda mampu bersikap netral dan tidak memihak. Karena secara naluri pelaku politik, tokoh masyarakat dan tokoh pemuda adalah sasaran utama untuk direkrut sebagai kader, pengurus, maupun simpatisan partai. Informan menjelaskan, "Karena wilayah kami luas, kami tidak bisa memantau, karenanya kami memanggil atau meminta tolong tokoh masyarakat setempat untuk datang membawakan nama-nama yang pantas untuk menjadi KPPS di daerah masingmasing" (wawancara P, 2017).

Terakir, politisasi oleh Penyelenggara pemilu sendiri hasil politisasi kades/lurah. "KPPS dibentuk oleh PPS. PPS mengundang masyarakat, PPS mengumpulkan masyarakat untuk membentuk KPPS, tokoh masyarakat yg ditanyakan. Kami mengundang yang sesuai dengan ketentuan peraturan perundang-undangan. Kecuali kalo jumlahnya tidak cukup, kita minta tokoh masyarakat untuk mencarikan" (wawancara S, 2017).

Dalam aturan dijelaskan bahwa KPU bekerjasama dengan pemerintah daerah setempat untuk melaksanakan proses rekrutmen PPK, PPS, dan KPPS. Tetapi, permasalahan timbul ketika peluang ini kemudian dimanfaatkan oknum, karena secara formal kegiatan yang mereka lakukan terkesan sesuai aturan. Tetapi secara informal, kegiatan yang mereka lakukan diselipi kepentingan politik tertentu. 
Grafik 1. Cross Check Perolehan Suara PAN pada Pilkada 2015 dan Bentuk Cara

Kerja Politisasi Badan Penyelenggara Pemilu Ad Hoc

Hasil Hitung TPS (Form C1) Kabupaten Tanjung Jabung Timur

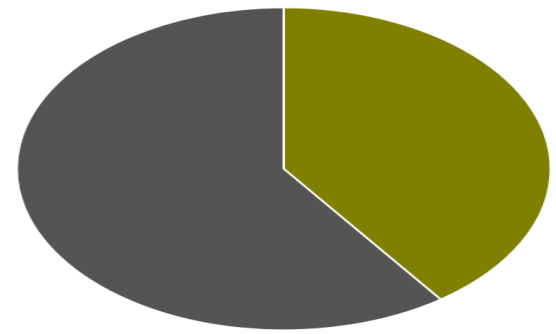

1 Hj. Dillah Hikmah Sari, ST dan Gatot Sumarto, SH

$2 \mathrm{H}$. Romi Hariyanto, SE dan H. Robby Nat

(50) Nahliansyah

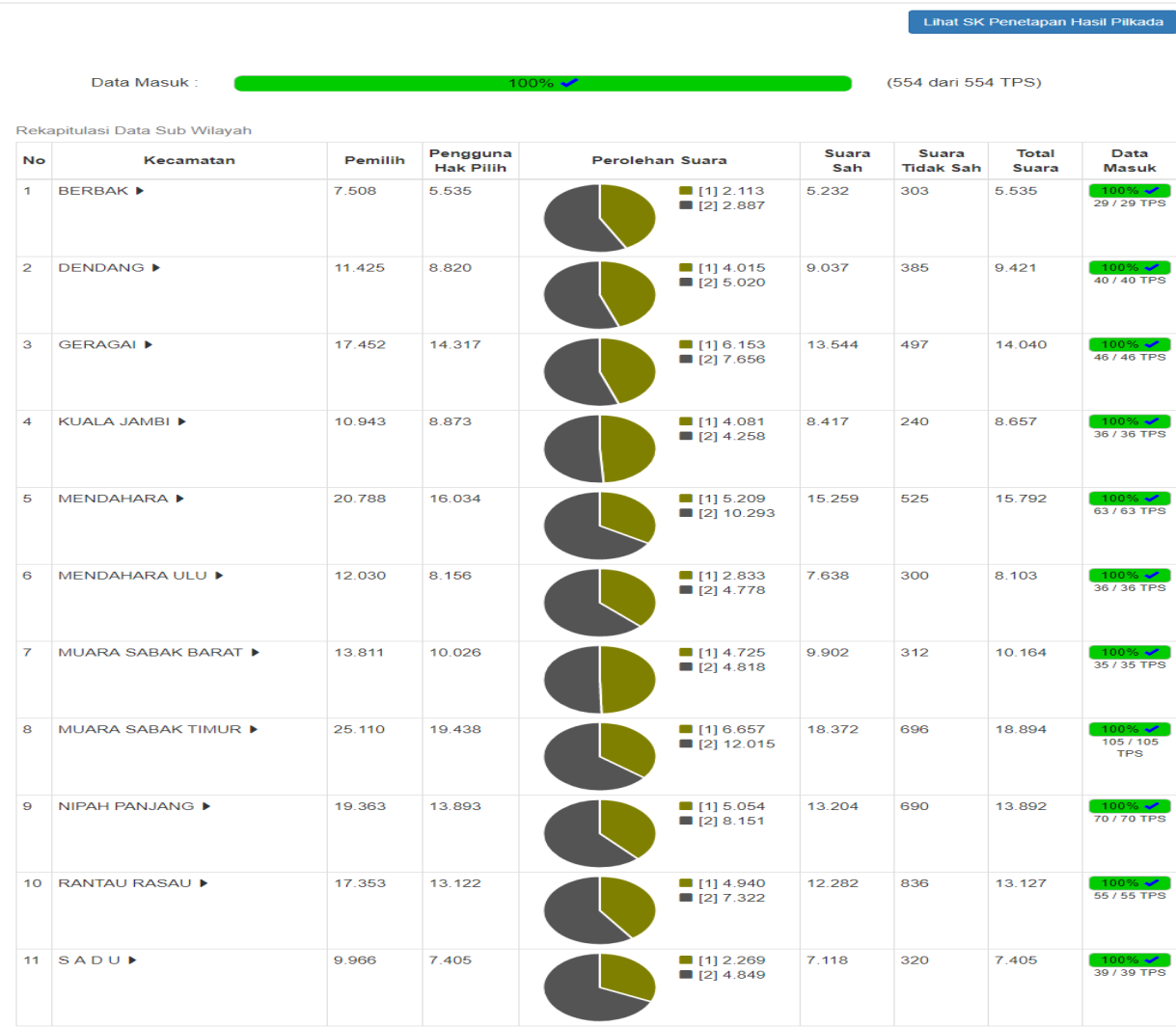

Sumber: https://pilkada2015.kpu.go.id/tanjabtimkab/

Paslon Nomor 1 bukan merupakan kandidat PAN dan Paslon Nomor 2 merupakan kandidat PAN. Apabila ditarik hubungan antara bentuk cara kerja politisasi di atas dikaitkan dengan perolehan suara kecamatan untuk PAN berdasarkan keterangan narasumber yang telah berhasil diwawancarai, diperoleh gambaran sebagai berikut. Pertama, Muara Sabak Timur, Mendahara Ulu, dan Berbak dengan proses rekrutmen PPS dan KPPS ada campur tangan kades/lurah yang dominan menunjukkan perolehan suara di Muara Sabak Timur (64,35\%), Mendahara Ulu (62,78\%), dan Berbak (57,74\%) untuk PAN. Kedua, Nipah Panjang dengan proses rekrutmen PPS didominasi oleh kades/lurah dan KPPS didominasi oleh Ketua RT/RW, Kadus, atau tokoh masyarakat dan pemuda menunjukkan perolehan suara 61,73\% untuk PAN. Ketiga, Kuala Jambi 
dan Muara Sabak Barat dengan proses rekrutmen KPPS rata-rata dilakukan atau didominasi oleh PPS menunjukkan perolehan suara di Kuala Jambi (51,06\%) dan Muara Sabak Barat (50,49\%) untuk PAN.

Sementara, jika memperhatikan belahan diagram secara umum pada tiap kecamatan, maka terlihat perolehan suara rata-rata PAN tiap kecamatan mendekati 60\%, kecuali dua kecamatan yaitu Kuala Jambi dan Muara Sabak Barat.

Berdasarkan analisis di atas, ternyata proses rekrutmen KPPS Kuala Jambi dan Muara Sabak Barat lebih didominasi PPS dibandingkan kecamatan lain yang rekrutmen KPPS-nya lebih didominasi kades/lurah, ketua RT/RW, kadus, tokoh masyarakat, maupun tokoh pemuda. Sehingga dapat dinilai bahwa PPS hasil politisasi yang bekerja mandiri dalam seleksi KPPS lebih rendah kadar bahaya politisasinya dibandingkan bentuk cara kerja politisasi lain.

Sementara melihat perbandingan antara desa/kelurahan yang sangat dominan peran kades/lurah dalam rekrutmen PPS maupun KPPS dengan desa/kelurahan yang didominasi kades/lurah tetapi juga oleh perangkat birokrasi lain seperti ketua RT, ketua RW, kadus, tokoh masyarakat dan tokoh pemuda, ternyata tidak terlalu terpaut jauh hasil perolehan suaranya, masing-masing masih di angka kurang lebih $60 \%$.

Tetapi mempertimbangkan jangkauan ruang lingkup politisasi dalam proses rekrutmen badan penyelenggara pemilu ad hoc, maka dominasi kades/lurah dinilai paling tinggi kadar bahaya politisasinya. Karena dominasi kades/lurah mampu mengintervensi rekrutmen pada dua level sekaligus yaitu PPS dan KPPS sementara bentuk cara kerja politisasi badan penyelenggara pemilu ad hoc lainnya hanya mampu menjangkau satu level.

Berikut ini penulis ilustrasikan Cara Kerja Politisasi Badan Penyelenggara Pemilu Ad Hoc di Desa Kota Harapan. Desa Kota Harapan tercatat mempunyai 1.609 pemilih dengan 9 TPS, tetapi hanya 1.145 warga yang menggunakan hak pilihnya. Kandidat PAN berhasil memenangkan kontestasi pilkada 2015 dengan mendapatkan sumbangan dukungan dari Desa Kota Harapan sebesar 782 suara (70,13\%) meninggalkan jauh perolehan suara lawan yang harus puas memperoleh 333 suara (29,87\%) dari keseluruhan jumlah suara.

Kades yang menjabat di Desa Kota Harapan bernama Muhamamd Tanri, sudah dua periode menjabat kades Kota Harapan dari tahun 2007 hingga 2019. Diperkirakan merupakan simpatisan PAN murni.

"Waktu itu kades menginginkan kami mencapai angka 70\% atau 80\% (untuk

PAN). Katanya, biar jadi anak kesayangan, sehingga kalau ada permintaan desa, yang atas gampang mengabulkan” (wawancara $\mathrm{R}, 2017$ ).

Sebagai simpatisan PAN, politisasi badan penyelenggara pemilu ad hoc yang dilakukan Muhammad Tanri terlihat begitu kentara. Selain menetapkan sendiri pengurus PPS dan KPPS, kades tersebut juga mengutarakan target suara yang ingin dicapainya kepada penyelenggara pemilu. Selain itu, Muhammad Tanri juga terbilang berani, 
karena Rahmansyah diketahui masyarakat setempat merupakan pengurus PAN tetapi kades tetap menunjuk Rahmansyah sebagai salah satu penyelenggara pemilu untuk TPS 7 di Desa Kota Harapan.

"Saya menjadi ketua KPPS ditunjuk langsung oleh kepala desa. PPS juga ditunjuk langsung dari Pak kades... Awalnya, anggota BPD menyuruh saya menjadi ketua KPPS melalui Rina (salah satu anggota yang juga ditunjuk sebagai anggota KPPS). Kok saya kenapa? Katanya karena kemarin Harun sudah masuk tim sukses HBA (tim lawan di tingkat provinsi) jadi tidak bisa lagi dimajukan jadi ketua KPPS. Tetapi kan saya... tau sendirikan Rina... atau Rina saja jadi ketua saya jadi anggota. Tidak bisa bang, jawab Rina, karena ini pak kades yang suruh. Saya mengajukan keberatan kepada kades, tetapi menurut kades tidak ada lagi orang makanya saya ditunjuk sebagai ketua KPPS.... Pernah ada pihak tim lawan yang mengetahui dan mengancam akan mengadukan saya apabila saya masih tetap menjadi ketua KPPS, segera saya sampaikan kepada kades, dan beliau meyakinkan saya. Selain itu saya juga telpon bang Firman anggota Dewan, dia tanya apakah nama saya masuk dalam daftar tim sukses, kata saya tidak. Saya cuma tim bayangan. katanya amanlah tuh man. Dan memang tidak terjadi apa-apa" (wawancara R, 2017).

Bentuk cara kerja politisasi badan penyelenggara pemilu ad hoc yang dijalankan Muhammad Tanri adalah dominasi peran kades/lurah yang mengintervensi proses rekrutmen PPS dan KPPS. Proses rekrutmen juga tidak melalui seleksi, tetapi kades melakukan penunjukan langsung baik untuk petugas PPS maupun KPPS. Beberapa tindakan kades sangat jelas melanggar aturan. Tetapi, ternyata sistem memberikan keleluasaan gerak bagi kades untuk memainkan peran politisasinya tanpa dinilai melanggar hukum secara formal.

Apabila memperhatikan perolehan suara di Desa Kota Harapan, tampaknya target perolehan suara yang diharapkan Muhammad Tanri cukup terealisasikan. PAN berhasil mendulang suara. Dari 9 TPS yang ada di desa tersebut, 8 TPS dimenangkan PAN dengan perolehan suara diantara 60\% hingga 80\%. Hanya TPS 9 suara PAN berhasil dikalahkan lawan sebesar 47,92\%.

"Dari TPS 1 hingga TPS 9 Kades yang mengatur dengan berkoordinasi dengan kadus. TPS 9 itu Parit IV, di darat (daerah perkebunan). PAN memang kalah di situ, suara di situ dikit, memang sejak awal tidak terlalu diperhitungkan. Kadus di sana sudah lama mau diganti karena tidak berpihak pada kades, tetapi tidak ada yang bisa menggantikannya, yang lain tidak bisa baca tulis. Kadusnya sudah tidak dipercaya kades, cuma karena tidak ada yang bisa diandalkan maka kadus tersebut tetap menjabat. Kades tidak tahu siapa orang yang pantas ditunjuk KPPS di sana maka menyerahkan sepenuhnya pada kadus. KPPS terpilih juga kurang dikoordinasikan... TPS 1 tempat tinggal Kades, TPS 3 tempat tinggal ketua DP Ranting PAN, TPS 4 dan 5 banyak pengurus PAN. Di TPS 9 tidak ada orang PAN, jadi mengandalkan kadus" (wawancara $\mathrm{R}, 2017$ ). 
Walaupun peran penyelenggara pemilu Desa Kota Harapan tidak terbukti sebagai pelaku penggelembungan atau penggembosan suara seperti yang diutarakan Junaidi (2016). PAN meyakini bahwa PPK, PPS dan KPPS sebagai 'orang mereka' mempunyai peran yang penting untuk mendukung kemenangan.

"Kami tidak berani mau buat curang, sebenarnya dengan penunjukan langsung, tetap KPPS dan PPS bisa bekerja profesional tanpa kecurangan. Lagi pula PAN tanpa kami berbuat curang juga pasti menang. Kami hanya menjadi pengawal suara, memastikan suara PAN tidak dicurangi lawan. (Narasumber menunjukkan dokumentasinya pada pewawancara berkaitan dengan penghitungan suara di TPS tempatnya bertugas)" (wawancara $\mathrm{R}, 2017$ ).

"Permainan yang dilakukan bukan berusaha untuk melakukan kecurangan atau permainan suara, tetapi bagaimana mempersiapkan DPT agar semua 'orangorang loyal mereka' yang punya hak pilih terjamin masuk dalam daftar dan dipastikan memilih pada hari pemilihan... Terdapat pembagian tugas dalam tim pemenangan PAN: penjaga suara (PPS, KPPS) dan penggerak suara (diluar PPS, KPPS). Pada hari $\mathrm{H}$, tugas penjaga suara adalah memperhatikan tindak-tanduk lawan, mencegah terjadinya kecurangan dari pihak lawan" (wawancara SA, 2017).

\section{Implikasi Politisasi Badan Penyelenggara Pemilu Ad Hoc}

Berdasarkan tidak adanya temuan dalam laporan pelanggaran Pilkada 2015 catatan Panwaslu Tanjung Jabung Timur dan wawancara narasumber, politisasi PPK tidak langsung berimplikasi pada rekapitulasi hasil penghitungan suara di kecamatan. Berdasarkan pengamatan di lapangan, sosialisasi dan akses informasi yang diberikan PPK tidak menunjukkan eksklusivitas pada salah satu kelompok calon. Berdasarkan hasil wawancara, untuk penyusunan Daftar Pemilih Tetap (DPT), narasumber menjelaskan bahwa PPK berrsama PPS mempersiapkan DPT dengan mengupayakan semua 'orangorang loyal PAN' yang punya hak pilih terjamin masuk dalam daftar dan dipastikan memilih pada hari pemilihan.

Sementara itu di kelurahan/desa, berdasarkan tidak adanya temuan dalam laporan pelanggaran Pilkada 2015 catatan Panwaslu Tanjung Jabung Timur dan wawancara narasumber, politisasi PPS tidak langsung berimplikasi pada rekapitulasi hasil penghitungan suara. Berdasarkan pengamatan di lapangan, sosialisasi dan akses informasi yang diberikan PPS tidak menunjukkan eksklusivitas pada salah satu kelompok calon. Berdasarkan hasil wawancara, untuk penyusunan Daftar Pemilih Tetap (DPT), narasumber menjelaskan bahwa PPK maupun PPS mempersiapkan DPT agar semua 'orang-orang loyal mereka' (baca: simpatisan PAN) yang punya hak pilih terjamin masuk dalam daftar dan dipastikan memilih pada hari pemilihan. Terdapat kecenderungan untuk menyerahkan otoritas memilih KPPS kepada kades/lurah, kadus, ketua RW, ketua RT, tokoh masyarakat, dan atau tokoh pemuda yang diperkirakan bersifat tidak netral. Hasilnya, ada kecenderungan untuk memilih KPPS yang diperkirakan memiliki afiliasi 
politik yang sama. PPDP (Petugas Pemuktahiran Data Pemilih) yang dipilih kurang bekerja secara maksimal.

"Tidak. Apa itu PPDP? Tidak ada petugas yang datang ke rumah untuk mendata kami langsung... Memang dalam DPT masih kadang ditemukan nama orang yang sudah tidak ada lagi orangnya" (wawancara $\mathrm{R}, 2017$ ).

Kemudian, di tingkat TPS, berdasarkan tidak adanya temuan dalam laporan pelanggaran Pilkada 2015 catatan Panwaslu Tanjung Jabung Timur dan wawancara narasumber, politisasi KPPS tidak langsung berimplikasi pada proses penghitungan dan hasil penghitungan suara. Badan penyelenggara pemilu ad hoc menjadi "Penjaga Suara", yaitu pengamat gerak-gerik lawan PAN dalam Pilkada 2015 yang diperkirakan akan melakukan kecurangan pada hari pencoblosan. Biasanya mereka bertindak cepat ketika terbukti kecurangan terjadi dan merugikan posisi PAN. Sementara apabila PAN memperoleh keuntungan dari pelanggaran tersebut, biasanya mereka bersikap acuh tak acuh dan tidak membuat laporan pelanggaran.

Selama tugas penyelenggara pemilu adalah mengurusi penyelenggaraan kontestasi politik, maka aspek sosial politik secara otomatis turut berpengaruh terhadap pola rekrutmen PPK, PPS, dan KPPS. Implikasinya tidak mungkin untuk menciptakan model rekrutmen PPK, PPS, dan KPPS yang ideal dan murni terlepas dari unsur pengaruh sosial-politik kemasyarakatan. Kedua, KPU hanya dapat mengupayakan meminimalisir usaha politisasi badan penyelenggara pemilu ad hoc dan dampak politisasi tersebut. Ketiga, beberapa usaha KPU dinilai cukup membantu untuk meminimalisir dampak dari politisasi penyelenggara pemilu ad hoc, diantaranya: a) Intervensi teknologi informasi pada proses rekapitulasi penghitungan suara dan scan $\mathrm{C} 1$ yang dapat menekan kecurangan penggembosan dan penggelembungan suara; b) Kehadiran tim survei pemilu independen yang saat ini sudah berbasis IT, sehingga sulit untuk memanipulasi data tanpa diketahui; c) PKPU Nomor 3 Tahun 2015 yang membatasi masa jabatan badan penyelenggara pemilu ad hoc yang hanya dua periode pemilu. ${ }^{3}$

\section{Penutup}

Berdasarkan pembahasan di atas, ada dua tahap politisasi yang bekerja dalam proses rekrutmen badan penyelenggara pemilu ad hoc di Tanjung Jabung Timur, yaitu politisasi birokrasi di tingkat kecamatan dan desa/kelurahan yang dilanjutkan dengan politisasi badan penyelenggara pemilu ad hoc. Cara kerja politisasi birokrasi di tingkat kecamatan dan desa/kelurahan melalui dua cara yaitu jalur PNS dan jalur Pilkades. Sementara cara kerja politisasi badan penyelenggara pemilu ad hoc melalui beberapa cara yaitu jalur camat, kades/lurah, kadus, ketua RW, ketua RT, tokoh masyarakat, tokoh pemuda, dan PPS hasil politisasi kades/lurah. Politisasi badan penyelenggara pemilu ad hoc yang dilakukan kades/lurah mengandung kadar politisasi paling tinggi, karena jangkauan pelaku melingkupi seleksi PPS dan KPPS. Pola dampak politisasi badan penyelenggara pemilu ad hoc, yaitu semakin rendah level hierarkinya maka semakin 
tinggi level politisasinya. Rekrutmen KPPS dinilai mengandung level politisasi paling tinggi. Hal ini disebabkan karena: (1) Proses rekrutmennya semakin ke bawah semakin longgar dan tidak spesifik aturannya; dan (2) Semakin ke bawah semakin kurang keterlibatan KPU Kabupaten/kota. Politisasi badan penyelenggara pemilu ad hoc apabila dikaitkan dengan siklus tahapan pemilu dan tugas pokok PPK, PPS, dan KPPS maka tidak langsung berimplikasi pada hasil dan rekapitulasi penghitungan suara serta sosialisasi penyelenggaraan pilkada. Tetapi langsung berimplikasi pada penyusunan DPT, pemilihan KPPS, kinerja PPDP, dan laporan pelanggaran pilkada.

Dengan demikian, perlu aturan yang detail mengenai proses rekrutmen badan penyelenggara pemilu ad hoc dimana KPU RI perlu mengatur lebih spesifik proses rekrutmen di tiap level, melarang penunjukan langsung sebagai salah satu metode rekrutmen badan penyelenggara pemilu ad hoc, dan mengupayakan agar KPU Kabupaten/kota perlu terlibat dalam proses rekrutmen badan penyelenggara pemilu ad hoc hingga ke level paling bawah. Hal lain, perlu intervensi teknologi pada rekrutmen Badan Penyelenggara Pemilu Ad Hoc. Teknologi dapat membantu mempermudah kerja KPU Kabupaten/kota, karena teknologi dapat dirancang untuk memuat 'pendaftaran dan seleksi mandiri', yaitu sebuah aplikasi rekrutmen yang memuat menu pendaftaran sekaligus menu seleksi otomatis yang dapat menentukan sendiri pelamar tersebut diterima atau tidak diterima.

\section{Ucapan Terima Kasih}

Penulis mengucapkan terimakasih kepada Amalinda Savirani selaku pembimbing tesis, para informan dan sesama peneliti pemilu untuk pendalaman diskusi.

\section{Pendanaan}

Penulis menerima bantuan pembiayaan untuk penyelesaian studi, penelitian, kepenulisan (authorship), dan publikasi dari Komisi Pemilihan Umum Republik Indonesia (KPU-RI).

\section{Daftar Pustaka}

Bayu Aji Dewantara, B. (2017). Politisasi Agama.

Deutsch, Merton and Coleman, P. T. (2000). The Handbook of Conflict Resolution Theory and Practice. San Francisco: Jossey-Bass Publishers.

Junaidi, V. (2016). Potret Pemilu Dalam Sengketa. Jurnal Pemilu Dan Demokrasi, Tayasan Perludem, 7.

Kartono, K. (1989). Pendidikan Politik Sebagai Bagian dari Pendidikan Orang Dewasa. Jogjakarta: Mandar Maju.

Martini, R. (2013). Politisasi Birokrasi di Indonesia. Retrieved February 2, 2020, from http://ejournal.undip.ac.id/index.php/politika/article/viewFile/4879/4425,

Norris, P., Frank, R. W., \& i Coma, F. M. (2014). Advancing Electoral Integrity. Oxford University Press.

RI, B. (2016). Simpul Penegak Demokrasi: Laporan Hasil Pengawasan Pemilihan Gubernur, Bupati, dan Walikota Serentak Tahun 2015. Jakarta: Bawaslu Republik Indonesia. 
Shaleh, A. Q. (2003). Agama Kekerasan. Prismasophie.

Surbakti, R., \& Nugroho, K. (2015). Studi tentang Desain Kelembagaan Pemilu yang Efektif.

The International IDEA. (2012). Manajemen Kepemiluan Selama Masa Transisi: Tantangan dan Peluang. Swedia: Publication Office: International IDEA.

Tjokrowinoto, M. (2001). Birokrasi dalam Polemik. Pusat Studi Kewilayahan Universitas Muhammadiyah Malang.

\section{Catatan}

${ }^{1}$ Hal ini sebagaimana diberitakan Tribun yang menuliskan, "Menurut M Iqbal Kusuma Farizan, Kuasa Hukum pemohon, pihak terkait telah melakukan pelanggaran Pemilukada, money politic, secara sistematis, terstruktur, dan masif, sehingga mempengaruhi perolehan suara klien mereka yaitu terpaut 9.275 suara... Selain itu, pelanggaran lainnya, yang bersifat terstruktur, adalah dugaan keberpihakan Bupati Tanjung Jabung Timur, terhadap pasangan Zumi Zola, dan Ambo Tang. "Modusnya dengan mengumpulkan seluruh camat dan memberikan instruksi agar memilih dan memenangkan Zumi Zola-Ambo Tang," kata Iqbal. Tidak hanya itu, Iqbal menyatakan, Bupati Tanjung Jabung Timur, diduga mengumpulkan kepala desa untuk mensukseskan pemenangan Zumi Zola dan Ambo Tang" (Tribun Jambi, 2011)

${ }^{2}$ Sebagaimana pemberitaan Tribun, "Dari saksi kami yang menjelaskan, sebagian besar pejabat ada yang diarahkan, baik camat, kepala dinas, kepala desa, berikut sampai ke bawah," jelasnya. "Saksi kami menyaksikan peristiwa pengorganisiran itu, karena saksi kami ada dari camat yang dinon-job-kan, ada juga saksi kami dari lurah yang dimutasikan, dan itu semua dijelaskan di hadapan majelis hakim," kata pria yang juga Wakil Bupati Tanjabtim itu." (Tribun Jambi, 2011).

3 Sesuai Surat Edaran KPU RI Nomor: 324/KPU/VI/2016 yang menekankan: a) Sosialisasi rekrutmen PPK, PPS, KPPS harus menggunakan sarana yang mudah diakses publik; b) Kades/Lurah dan BPD tidak hanya mengirimkan usulan nama PPS, tetapi juga para pendaftar calon PPS beserta data pendukungnya; c) KPU kab/kota diminta untuk mengatur ketentuan teknis seleksi anggota PPK, PPS, dan KPPS; dan d) KPU Provinsi harus melakukan pengendalian dan pemantaun berkaitan dengan rekrutmen PPK, PPS, dan KPPS.

\section{Penulis}

Mardiana adalah alumnus Pascasarjana Politik Pemerintahan, Universitas Gadjah Mada dan Staf Pelaksana KPU Kabupaten Tanjung Jabung Timur 